\title{
Neonatal Adaptation: Naloxone Increases the Catecholamine Surge at Birth
}

\author{
JAMES F. PADBURY, YOUTARO AGATA, DANIEL H. POLK, DORA L. WANG, AND \\ CARLOS C. CALLEGARI \\ Perinatal Research Laboratory, Department of Pediatrics, UCLA School of Medicine, Harbor-UCLA Medical \\ Center, Torrance, California 90509
}

\begin{abstract}
A marked increase in plasma catecholamines at birth has been described in animals and man. Because the factors that regulate catecholamine secretion are incompletely understood and because it has recently been suggested that endogenous opiates are important in the regulation of catecholamine secretion, we designed studies to determine the influence of opiate receptor blockade prior to delivery on the increase in plasma catecholamines at birth. Term fetal sheep were delivered by cesarean section and randomly assigned to receive naloxone or vehicle. Naloxone was given just prior to umbilical cord cutting as a $2 \mathrm{mg} / \mathrm{kg}$ bolus followed by $2 \mathrm{mg} / \mathrm{kg} / \mathrm{h}$. Naloxone administration resulted in significantly greater peak levels of plasma norepinephrine (peak levels of $1.5 \pm 0.4$ versus 0.9 $\pm 0.1 \mathrm{ng} / \mathrm{ml}$ ) and epinephrine (peak levels of $1.4 \pm 0.7$ versus $0.9 \pm 0.3 \mathrm{ng} / \mathrm{ml}$ ) and higher norepinephrine values throughout the study period. Naloxone administration was associated with significantly elevated heart rate (peak 184 \pm 12 versus $207 \pm 13$ beats per $\mathrm{min}$ ) and blood pressure (peak $95 \pm 6$ versus $88 \pm 2 \mathrm{~mm} \mathrm{Hg}$ ). These studies demonstrate that opiate receptor blockade from birth markedly augments the neonatal sympathoadrenal response in the term newborn lamb. (Pediatr Res 21:590593,1987 )
\end{abstract}

\section{Abbreviations}

NE, norepinephrine

$\mathrm{E}$, epinephrine

$\beta$ END, $\beta$-endorphin

ENK, enkephalin

EGTA, (ethyleneglycol-bis-[ $\beta$-aminoethyl ether]-

$\mathbf{N}, \mathbf{N}, \mathbf{N}^{\prime}, \mathbf{N}^{\prime}$-tetracetic acid)

ANOVA, analysis of variance

Fetal and newborn animals secrete catecholamines in response to a variety of stimuli including hypoxia (1), hemorrhage (2), hypothermia (3), labor (4), and delivery (5). The marked increase in catecholamine secretion at birth is particularly important because of the wide range of physiological changes which occur at birth and the importance of the sympathoadrenal system in modulating these changes. In the chronically catheterized fetal sheep, plasma catecholamines begin to rise in the last $3 \mathrm{~h}$ of

Received September 30, 1986; accepted January 9, 1987.

Address correspondence to James F. Padbury, M.D., Department of Pediatrics, Harbor-UCLA Medical Center, 1000 West Carson Street, Building A-17, Torrance, CA 90509.

Supported by Grant HDI8014 from the National Institutes of Health and a Basil O'Connor Starter Research Grant from the National Foundation March of Dimes. spontaneous labor prior to delivery (4). There is then a further augmentation in plasma levels of both $\mathrm{NE}$ and $\mathrm{E}$ following delivery and cord cutting (6). We were interested to extend our observations to study the factors that regulate catecholamine release at birth.

Two levels of control of catecholamine release have been recognized, including $\alpha 2$ receptor-mediated presynaptic inhibition of NE release and inhibition by endogenous opiate peptides. $\beta$ END is secreted in response to stress (7) and degrees of hypoxia in fetal sheep known to produce marked catecholamine secretion result in markedly increased levels of circulating $\beta$ END (8). Catecholamines and ENK are costored and secreted by the adrenal medulla in response to cholinergic or splanchnic nerve stimulation (9-12). Opiate peptides inhibit catecholamine release by inhibition of neurotransmission in sympathetic ganglia (13, 14) and inhibition of adrenal medullary catecholamine secretion (15). The physiological significance of these observations in vivo is unclear. In the present study, in order to investigate the role of endogenous opiates in vivo as modulators of sympathoadrenal activity at birth, we compared plasma catecholamine levels with and without continuous opiate receptor blockade following umbilical cord cutting in the term fetal sheep.

\section{MATERIALS AND METHODS}

Animals. To control the effects of labor, manipulation, and delivery on sympathoadrenal activity, we used the acutely exteriorized fetal sheep model as described previously (6). Time-dated fetuses were delivered using maternal spinal/epidural anesthesia. The fetal hindlimb was delivered through a small uterine incision, infiltrated with local anesthetic and the dorsal hindlimb artery was catheterized. The hindlimb was returned to the uterus and the incision closed by a purse-string suture. Through a second hysterotomy incision, the fetal head was delivered and fetal breathing was prevented by placing a warm saline filled glove over the head. Following local anesthetic infiltration, a tracheostomy was performed through a midline longitudinal incision with secure placement of an appropriately sized uncuffed endotracheal tube. Breathing was prevented by clamping the endotracheal tube. Breathing efforts were rarely observed prior to umbilical cord cutting. The animals were then delivered onto the maternal abdomen and allowed to stabilize for 20 to $30 \mathrm{~min}$. Care was taken to avoid traction or trauma to the umbilical cord. Heart rate and blood pressure were measured continuously with a pressure transducer connected to the arterial catheter. Body temperature was monitored with an indwelling rectal probe.

Immediately following umbilical cord cutting the animals were ventilated by hand with $100 \%$ oxygen and then placed on timecycled, pressure-limited Sechrist infant ventilators. To prevent movement, the animals were given $0.1 \mathrm{mg} / \mathrm{kg}$ pancuronium bromide. The ventilator was adjusted to maintain an arterial $\mathrm{pO}_{2}$ of $100-150$ torr and arterial $\mathrm{pH}$ and $\mathrm{pCO}_{2}$ within normal values. 
The lambs were dried superficially and supported under an infant radiant warmer with supplemental heat lamps as necessary to maintain body temperature at $39 \pm 1.0^{\circ} \mathrm{C}$. A continuous infusion of normal saline at a rate of $4 \mathrm{ml} / \mathrm{kg} / \mathrm{h}$ was administered.

Opiate receptor blockade. For the opiate receptor blockade, fetuses from eight time-dated pregnant ewes with twin gestations at term (145 \pm 1 day) were randomly assigned to receive either naloxone or control infusion following cord cutting so that if the first fetus of a twin pair received naloxone the second served as a control. In each case the second fetus was delivered within $1 \mathrm{~h}$ of the first twin and had comparable blood gas values and catecholamine levels. Naloxone was administered as a $2 \mathrm{ml}$ injection just prior to cord cutting at a dose of $2 \mathrm{mg} / \mathrm{kg}$ estimated fetal body weight followed by $2 \mathrm{mg} / \mathrm{kg} / \mathrm{h}$ via the hindlimb catheter. This regimen has been shown to reverse the circulatory collapse in hemorrhagic and endotoxic shock in dogs and rats (16). Control fetuses received an equivalent amount of normal saline. Blood samples for catecholamines and arterial blood gas measurements were drawn immediately after catheterization, serially after delivery until the time of cord cutting, and sequentially thereafter as described previously (6). All blood samples, heart rate, and blood pressure measurements after cord cutting were done using the umbilical arterial catheter. A total of $3 \mathrm{ml}$ whole blood was removed at each sampling time and the blood was replaced immediately with heparinized residual placental blood drawn following delivery.

In a subset of the control animals $(n=6)$ a similar bolus followed by a continuous infusion of naloxone was given beginning at $4 \mathrm{~h}$ of age. Samples were obtained for arterial blood gases and catecholamine measurements prior to the bolus and at 2, 5, 15,30 , and 60 min during the continuous infusion.

Analytical techniques. Blood samples for catecholamine measurements were placed immediately into chilled tubes containing EGTA and reduced glutathione. Plasma was separated, rapidly frozen, and stored at $-70^{\circ} \mathrm{C}$ for assay within $2 \mathrm{wk}$. Plasma catecholamine concentrations were determined by radioenzymatic assay sensitive to $10-20 \mathrm{pg} / \mathrm{ml}$ of $\mathrm{NE}$ and $\mathrm{E}$ (17). Blood gases were measured on a Radiometer blood gas instrument maintained at $39^{\circ} \mathrm{C}$.

Statistical analysis. All data are presented as mean \pm SEM. Comparisons between sequential plasma catecholamine concentrations or biophysical parameters (factor A) in control or naloxone-infused animals (factor B) were made with two-way ANOVA with replication (18). Individual comparisons between or within groups at individual time points were conducted using unpaired Student's $t$ test.

\section{RESULTS}

The sequential plasma $\mathrm{NE}$ and $\mathrm{E}$ values for naloxone treated and control animals are shown in Figure 1. There is a brief, modest elevation in plasma catecholamine levels following catheterization and delivery, similar to previous observations (6). NE rose to a peak of $515 \pm 121 \mathrm{pg} / \mathrm{ml}$ and $E$ to $70 \pm 37 \mathrm{pg} / \mathrm{ml}$ during the exteriorization. These values return to baseline during the stabilization period. This allows separation of the neonatal catecholamine surge from the effects of manipulation and delivery. Plasma NE values just prior to cord cutting were $382 \pm 76$ $\mathrm{pg} / \mathrm{ml}$ in control animals and $418 \pm 77 \mathrm{pg} / \mathrm{ml}$ in naloxonetreated animals. Plasma $E$ values were $40 \pm 17$ and $44 \pm 7 \mathrm{pg} /$ $\mathrm{ml}$, respectively. Both the baseline $\mathrm{NE}$ and the baseline $\mathrm{E}$ values were statistically similar by ANOVA in treated and control animals. In all twin studies the second twin was in stable physiological condition prior to cord cutting as evidenced by normal blood gases and baseline catecholamine values which were not statistically different from the first twin. Fetal and newborn body temperatures remained within a normal range $\left(39 \pm 1^{\circ} \mathrm{C}\right)$ throughout the experiments.

Following cord cutting there were marked increases in both plasma NE and $\mathrm{E}$ in naloxone and control animals. The nalox-
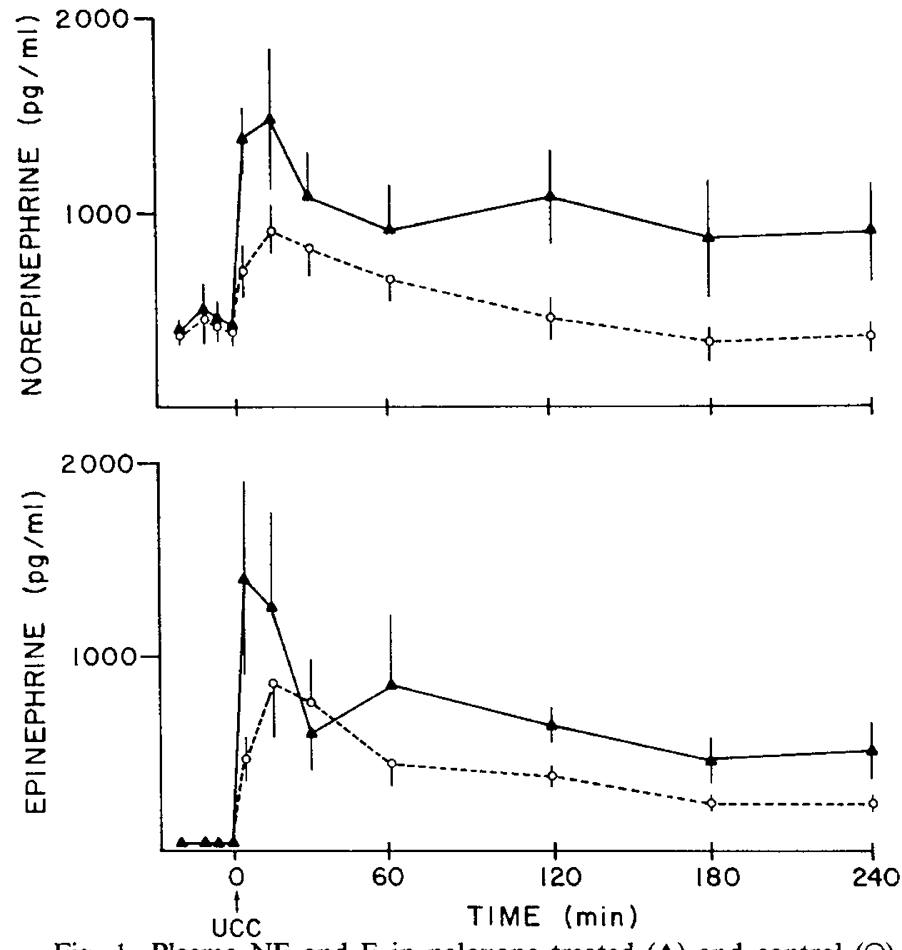

Fig. 1. Plasma NE and $\mathrm{E}$ in naloxone treated $(\boldsymbol{\Delta})$ and control $(\mathrm{O})$ newborn sheep following delivery. $U C C$, umbilical cord cutting. Naloxone treatment regimen as described in "Materials and methods."

one-infused animals had higher peak NE and $\mathrm{E}$ than the control animals and higher concentrations throughout the period of the study $(p<0.01$ by ANOVA). The peak plasma NE level in the naloxone-infused animals was $1473 \pm 362 \mathrm{pg} / \mathrm{ml}$ at $15 \mathrm{~min}$ versus $909 \pm 127 \mathrm{pg} / \mathrm{ml}$ in the controls. The peak $\mathrm{E}$ concentrations also occurred at 15 min in both groups (1398 \pm 698 versus $864 \pm 278 \mathrm{pg} / \mathrm{ml}$, respectively). These differences were both significant $(p<0.01)$. There was more variability in the plasma E responses following naloxone than in the NE values. However, all animals "responded"; i.e. the naloxone-treated twin had higher NE and E values and the results would be similar if expressed as percentage change from baseline prior to cord cutting.

The results of the serial arterial blood gas, heart rate, and blood pressure from naloxone treated and the control animals are shown in Figure 2. The initial increase in $\mathrm{pO}_{2}$ after cord cutting and ventilation was followed by adjustments in fractional inspired oxygen concentration to maintain a $\mathrm{pO}_{2}$ of $100-150 \mathrm{~mm}$ $\mathrm{Hg}$. Arterial $\mathrm{pCO}_{2}$ and $\mathrm{pH}$ were within physiological limits. The similar arterial blood gas and $\mathrm{pH}$ values demonstrated the comparable physiological state of the two groups. Heart rate and systolic blood pressure were both significantly elevated in naloxone-treated animals ( $p<0.01$ by ANOVA). Peak heart rate in the naloxone animals was $207 \pm 13$ beats per min at $60 \mathrm{~min}$ versus $184 \pm 12$ beats per min at $60 \mathrm{~min}$ in the controls. Peak systolic pressures were $95 \pm 6 \mathrm{~mm} \mathrm{Hg}$ at 60 min versus $88 \pm 2$ $\mathrm{mm} \mathrm{Hg}$ at $60 \mathrm{~min}$, respectively.

Serial $\mathrm{NE}$ and $\mathrm{E}$ levels following the injection and continuous infusion of naloxone at $4 \mathrm{~h}$ of age are shown for the control animals in Figure 3. By $4 \mathrm{~h}$ of age plasma NE levels had returned to $342 \pm 78 \mathrm{pg} / \mathrm{ml}$, a value similar to the baseline level prior to cord cutting $(382 \pm 76 \mathrm{pg} / \mathrm{ml})$. The plasma E concentration at 4 $\mathrm{h}$ of age was $271 \pm 24 \mathrm{pg} / \mathrm{ml}$, a level significantly greater than the baseline value of $60 \pm 24 \mathrm{pg} / \mathrm{ml}$ just prior to cord cutting. Following naloxone administration, there was a small increase in plasma NE concentration to a maximum of $494 \mathrm{pg} / \mathrm{ml}$ at 5 min. There was a greater increase in plasma $\mathrm{E}$ concentration, which rose to a peak of $509 \mathrm{pg} / \mathrm{ml}$ at $2 \mathrm{~min}$. Neither of these 

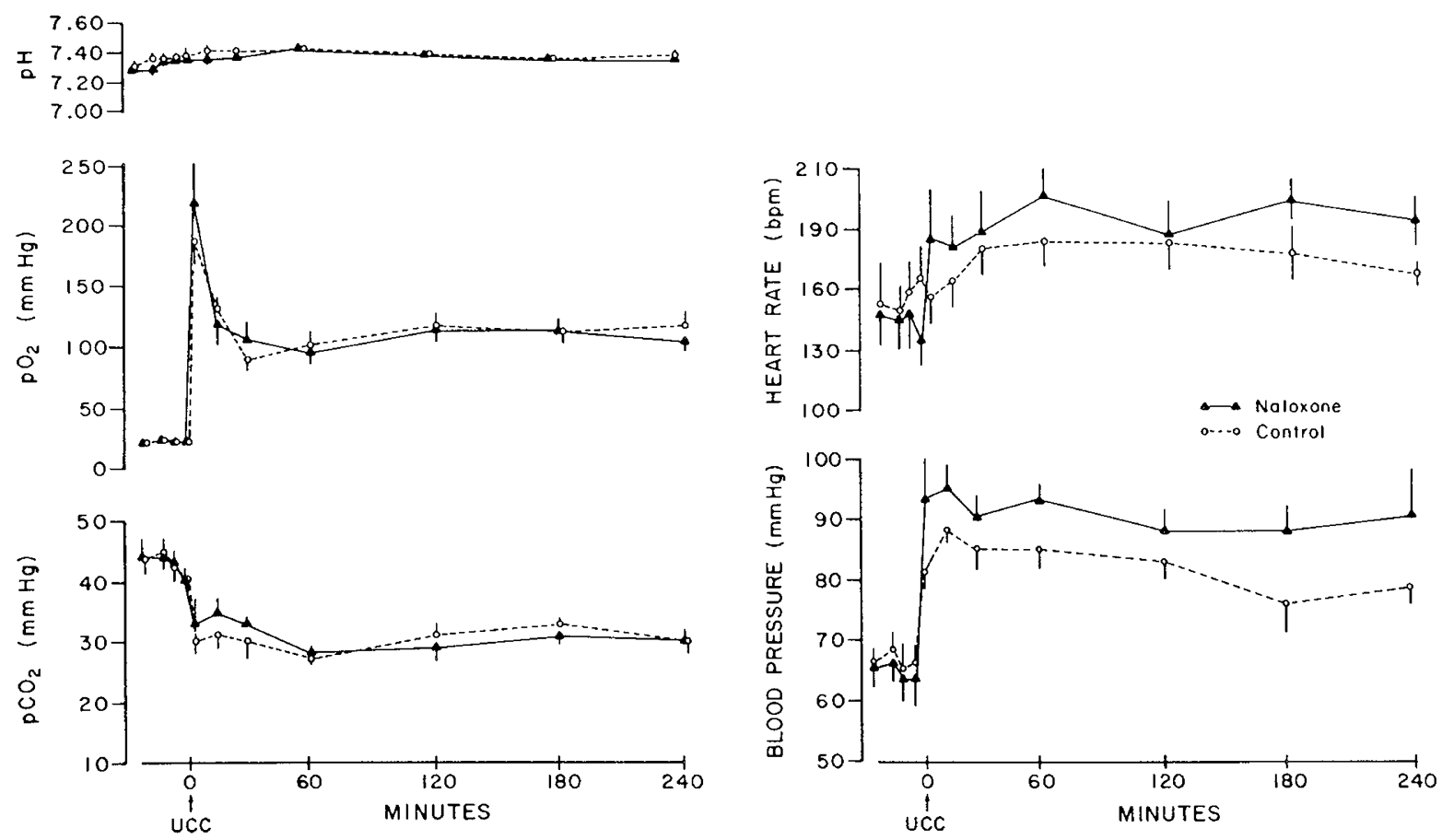

Fig. 2. Serial blood gases, heart rate, and systolic blood pressure in naloxone-treated $(\mathbf{\Lambda})$ and control $(O)$ newborn sheep following delivery. UCC, umbilical cord cutting. Naloxone treatment as described in "Materials and methods."

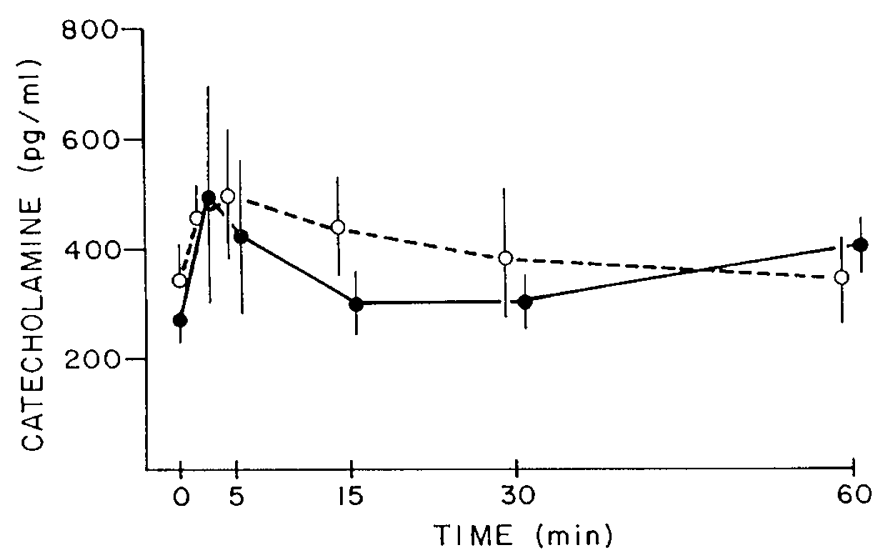

Fig. 3. Plasma NE $(O)$ and $\mathrm{E}(\bullet)$ in term sheep treated with naloxone at $4 \mathrm{~h}$ of age.

values nor the overall responses were significantly different from the pretreatment values. There were no significant blood gas, heart rate, or blood pressure changes following naloxone administration to control animals at $4 \mathrm{~h}$ of age.

\section{DISCUSSION}

The present results demonstrate that opiate receptor blockade increases the catecholamine surge at birth. We observed higher concentrations of circulating $\mathrm{NE}$ and $\mathrm{E}$ in sheep which received a continuous infusion of naloxone from birth when compared to control animals. Not only were peak plasma levels of NE and $\mathrm{E}$ greater in the naloxone-infused animals but the higher NE concentrations were sustained throughout the period of observation. The reliability of these differences in plasma catecholamines is supported by the similarity in plasma catecholamine responses of the control animals in this study and the term animals of comparable gestational ages reported in previous studies using this model $(6,19)$. The physiological importance of these concentration differences is suggested by the elevations in heart rate and blood pressure and seen in the naloxone-infused animals.

It is unclear whether the naloxone was antagonizing opiate peptide inhibition of sympathoadrenal activity centrally or peripherally and whether the higher circulating NE values were derived from sympathetic nerves or adrenal medullary secretion. The distribution of endogenous opiates and their receptors throughout the nervous system suggests their importance in the regulation of autonomic function. Opiate peptides have been localized in sympathetic ganglia (20), preganglionic nerve terminals (20-22), the adrenal medulla $(20,22)$, and the anterior pituitary (7) and in specific brainstem and hypothalamic nuclei (16). The effectiveness of intracisternal naloxone in shock models at doses which have no effect when administered peripherally suggests that one of their primary actions is to antagonize endogenous opiate inhibition of sympathoadrenal outflow at central autonomic sites. The relatively high dose of naloxone used in this study has been shown to be effective at these central nervous system sites $(16,23)$. It is also unclear which opiate receptor subtypes were antagonized by this large dose of naloxone. $\mathrm{Mu}$ receptors are antagonized at lower doses of naloxone than $\delta$ or $\kappa$ receptors (24), but the dosage used in this study does not permit discrimination of action at opiate receptor subtypes. It is also possible that other neurotransmitter/modulator systems were affected.

A potential role for adrenal enkephalins in the regulation of adrenal medullary catecholamine release in the developing rat has also been suggested. Neonatal rats secrete adrenal catecholamines directly in response to hypoxia or reserpine prior to the development of splanchnic nerve innervation, and thus potential central control $(25,26)$. Pretreatment with naloxone potentiates whereas methadone inhibits this reserpine-induced adrenal catecholamine depletion in neonatal rats but not adults following the development of an intact splanchnic innervation. In the fetal sheep a similar developmental transition in direct versus neural control of adrenal medullary catecholamine secretion takes place between approximately 130 days gestation and term (145-150 days) (27). In the present study we saw an increase in adrenal $\mathrm{E}$ 
secretion in the naloxone-treated group. However, because these were term sheep it is unclear whether this was due to altered central or peripheral regulation of adrenal E secretion. Further in vivo physiological studies are needed to clarify this mechanism.

Plasma catecholamines have been measured before and after induced hemorrhage in adult rabbits and following naloxone administration. Naloxone caused a nearly $100 \%$ increase in circulating NE and return of blood pressure to normal with a much smaller increase in plasma $E$ (28). In adult humans with septic shock, naloxone administration evoked a 10 -fold increase in plasma $E$ levels associated with improvements in circulatory function (29). Similar improvements in blood pressure and perfusion following naloxone have been observed in septic newborn humans (30) and neonatal piglets (31). In contrast, fentanyl, a potent opiate agonist, causes a dose-dependent inhibition of plasma NE and E in humans (32) and adult dogs (33) as well as decreases in heart rate, blood pressure, and cardiac output (33). The effect on NE is greater than $E$. These effects are all reversed by naloxone administration.

After $4 \mathrm{~h}$, circulating plasma NE and $\mathrm{E}$ concentrations in control animals had returned nearly to baseline values. Naloxone administration at this time had no significant effect on circulating plasma catecholamine levels. These results, considered with the early naloxone infusion results, suggest that endogenous opiate peptides are important inhibitors of sympathoadrenal activity in vivo but that this regulation is most important during periods of increased sympathoadrenal activity (34).

The potential role of endogenous opiates in regulating the enhanced sympathoadrenal activity seen at birth is substantial. Elevated levels of circulating endorphins and related peptides are seen in laboring women and newborn infants (35). Significant functional alterations in a variety of organ systems are required for successful neonatal adaptation to extrauterine life. These include changes in the cardiovascular system, pulmonary adaptation, thermogenesis and mobilization of energy substrates, and onset of respiration and establishment of respiratory control. Ample evidence exists to suggest that increased sympathoadrenal activity is vital to these adaptive changes. Central or peripheral regulation of sympathoadrenal involvement in these aspects of neonatal adaptation should provide fruitful areas of investigation of the physiological role of endogenous opiates.

\section{REFERENCES}

1. Cohen WR, Piasecki GJ, Jackson BT 1982 Plasma catecholamines during hypoxemia in fetal lamb. Am J Physiol 243:R520-R525

2. Jones CM, Rose JC, Kelly RT, Hargrave BY 1985 Catecholamine responses in fetal lambs subjected to hemorrhage. Am J Obstet Gynecol 151:475-478

3. Gunn TR, Johnson BM, Iwamoto HS, Fraser M, Nicholls MG, Gluckman PD 1985 Haemodynamic and catecholamine responses to hypothermia in the fetal sheep in utero. J Dev Physiol 7:241-249

4. Eliot RJ, Klein AH, Glatz TH, Nathanielsz PW, Fisher DA 1981 Plasma norepinephrine, epinephrine, and dopamine concentrations in maternal and fetal sheep during spontaneous parturition and in premature sheep during cortisol-induced parturition. Endocrinology 108:1678-1682

5. Lagercrantz H, Bistoletti $P 1973$ Catecholamine release in the newborn infant at birth. Pediatr Res 11:889-893

6. Padbury JF, Polk DH, Newnham JP, Lam RW 1985 Neonatal adaptation: greater sympathoadrenal response in preterm than term fetal sheep at birth. Am J Physiol 248:E443-E449

7. Guillemin R, Vargo TM, Rossier J, Minick S, Ling N, Rivier C, Vale W, Bloom F 1977 Beta-endorphin and adrenal corticotropin are secreted concomitantly by the pituitary gland. Science 197:1367-1369

8. Wardlaw SL, Stark RI, Daniel S, Frantz AG 1981 Effects of hypoxia on $\beta$ endorphin and $\beta$-lipotropin release in fetal, newborn, and maternal sheep.
Endocrinology 108:1710-1715

9. Barron BA, Hexum TD 1984 Release of catecholamines and $\left[\mathrm{Met}^{5}\right]$ enkephalin immunoreactive material from perfused bovine adrenal glands. Eur J Pharmacol 106:593-599

10. Chaminade M, Foutz AS, Rossier J 1984 Co-release of enkephalins and precursors with catecholamines from the perfused cat adrenal gland in situ. J Physiol 353:157-169

11. Hanbauer I, Kelly GD, Saiani L, Yang HYT $1982\left[\mathrm{Met}^{5}\right]$-enkephalin-like peptides of the adrenal medulla: Release by nerve stimulation and functional implications. Peptides 3:469-473

12. Viveros $\mathrm{OH}$, Diliberto EJ Jr, Hazum E, Chang K-J 1979 Opiate-like materials in the adrenal medulla: Evidence for storage and secretion with catecholamines. Mol Pharmacol 16:1101-1108

13. Cherubini E, Morita K, North RA 1985 Opioid inhibition of synaptic transmission in the guinea-pig myenteric plexus. Br J Pharmacol 85:805-817

14. Konishi S, Tsunoo A, Otsuka M 1981 Enkephalin as a transmitter for presynaptic inhibition in sympathetic ganglia. Nature 294:80-82

15. Kumakura K, Karoun F, Guidotti A, Costa E 1980 Modulation of nicotinic receptors by opiate receptor agonist in cultured adrenal chromaffin cells. Nature 283:489-492

16. Holaday JW 1983 Cardiovascular effects of endogenous opiate systems. Ann Rev Pharmacol Toxicol 25:541-594

17. Johnson GA, Peuler JD 1977 Simultaneous single isotope radioenzymatic assay of plasma norepinephrine, epinephrine and dopamine. Life Sci 21:625636

18. Sokol R, Rohlf F 1969 Biometry. Freeman, San Francisco, pp 299-328

19. Padbury JF, Diakomanolis ES, Hobel CJ, Perelman A, Fisher DA 1981 Neonatal adaptation: sympathoadrenal response to umbilical cord cutting. Pediatr Res 15:1483-1487

20. Schultzberg M, Hokfelt T, Lundberg JM, Terenius L, Elfvin LG, Elde R 1978 Enkephalin-like immunoreactivity in nerve-terminals in sympathetic ganglia and adrenal medulla and in adrenal medullary gland cells. Acta Physiol Scand 103:475-477

21. Hervonen A, Pickel VM, Joh TH, Reis TJ, Linnoila I, Miller RJ 1981 Immunohistochemical localization of the catecholamine-synthesizing enzymes, substance $P$ and enkephalin in the human fetal sympathetic ganglion. Cell Tissue Res 214:33-42

22. Schultzberg M, Lundberg JM, Horsfelt T, Terenius L, Brandt J, Elde RP, Goldstein M 1978 Enkephalin-like immunoreactivity in gland cells and nerve terminals of the adrenal medulia. Neuroscience 3:1169-1186

23. Holaday JW, D'Amato RJ, Ruvio BA, Feuerstein G, Faden AI 1983 Adrenalectomy blocks pressor responses to naloxone in endotoxic shock: evidence for sympathomedullary involvement. Circ Shock 11:201-210

24. Gordon FJ 1986 Central opioid receptors and baroreflex control of sympathetic and cardiovascular function. J Pharmacol Exp Ther 237:428

25. Chantry CJ, Seidler FJ, Slotkin TA 1982 Non-neurogenic mechanism for reserpine-induced release of catecholamines from the adrenal medulla of neonatal rats: possible modulation by opiate receptors. Neuroscience 7:673678

26. Seidler FJ, Slotkin TA 1985 Adrenomedullary function in the neonatal rat: responses to acute hypoxia. J Physiol 358:I-16

27. Comline RS, Silver M 1961 The release of adrenaline and noradrenaline from the adrenal glands of the foetal sheep. J Physiol 156:424-444

28. Schadt JC, Gaddis RR 1985 Endogenous opiate peptides may limit norepinephrine release during hemorrhage. J Pharmacol Exp Ther 232:656-660

29. Hughes GS 1984 Naloxone and methylprednisolone sodium succinate enhance sympathomedullary discharge in patients with septic shock. Life Sci 35:2319 2326

30. Catterton Z, Howick J, Oliver S 1984 Naloxone in neonatal septic shock. Clin Res 32:898A

31. Lobe TE, Dobkin ED, Gore D, Bhatia J, Linares HA, Traber DL 1986 Comparative effects of dopamine, naloxone, and prostacyclin in the resuscitation of fecal-Escherichia coli peritonitis-induced septic shock in neonatal swine. J Pediatr Surg 21:539-544

32. Patharl KS, Anton AH, Sutheimer CA 1985 Effects of low dose morphine and fentanyl infusions on urinary and plasma catecholamine concentrations during scoliosis surgery. Anesth Analg 64:509-514

33. Flacke JW, Flacke WE, Bloor BC, Olewine S 1983 Effects of fentanyl, naloxone and clonidine on hemodynamics and plasma catecholamine levels in dogs. Anesth Analg 62:305-313

34. Caffrey JL, Wooldridge CB, Gaugl JF 1985 The interaction of endogenous opiates with autonomic circulatory control in the dog. Circ Shock 17:233242

35. Kofinas GD, Kofinas AD, Tavakoli FM 1985 Maternal and fetal $\beta$-endorphin release in response to the stress of labor and delivery. Am J Obstet Gynecol 152:56-59 